\title{
Month-of-the-year and pre-holiday seasonality
}

in African stock markets

Paul Alagidede

Stirling Economics Discussion Paper 2008-23

November 2008

Online at http://www.economics.stir.ac.uk 


\title{
Month-of-the-year and pre-holiday seasonality in African stock markets
}

\author{
Paul Alagidede \\ Department of Economics, University of Stirling, Stirling, FK9 4LA, UK \\ paul.alagidede@stir.ac.uk
}

\begin{abstract}
Seasonal anomalies (calendar effects) may be loosely referred to as the tendency for financial asset returns to display systematic patterns at certain times of the day, week, month or year. Two popular calendar effects are investigated for African stock returns: the month-of-the-year and the pre-holiday effects, and their implication for stock market efficiency. We extend the traditional approach of modelling anomalies using OLS regressions and, examine both the mean and conditional variance. We find high and significant returns in days preceding a public holiday for South Africa, but this finding is not applicable to the other stock markets in our sample. Our results also indicate that the month-of-the-year effect is prevalent in African stock returns. However, due to liquidity and round trip transactions cost the anomalies uncovered may not necessarily violate the no-arbitrage condition. Finally we discuss promising areas for future research using developing stock markets data.
\end{abstract}

Keywords: Calendar effects, African stock markets, month of the year and pre-holiday effects

JEL: C22, C52, G10 


\section{Introduction}

The area of academic and practitioner research in financial economics that has generated the most excitement and attracted the most attention over the past four decades concerns persistent cross sectional and time series patterns that have been documented world-wide. Given certain simplifying assumptions, the capital asset pricing model (CAPM) states that the return on any security is linearly related to that security's systematic risk (or beta) measured relative to the market portfolio of all securities. If the CAPM is an accurate description of the way assets are priced, a positive linear relation should be observed when average portfolio returns are compared to portfolio betas. Further, when beta is included as an explanatory variable, no other variable should be able to explain cross sectional differences in average returns. This is consistent with the notion of market efficiency.

However, a growing number of studies suggest that betas of common stocks do not adequately explain cross sectional differences in stock returns. Instead, a number of variables, such as firm size, ratio of book to market, and price/earning ratios, that have no basis in extant theoretical models, seem to have significant predictive ability. For example, Basu (1977) and Banz (1981) found that the ratio of price to earnings and market capitalisation of common equity, respectively, provided considerably more explanatory power than beta. Also, stock returns are found to be systematically higher or lower depending on the time of the day, day of the week, and month of the year. The month-of-the-year and turn-of-the-month effect postulates that returns are estimated to be higher in the month of January, and especially, in the first few trading days of the month (see Roseff and Kinney, 1976, Keim, 1983 and Gultekin and Gultekin, 1983) than other months of the year. Over the years, evidence show that returns observed on days preceding a public holiday are, on average, many times greater than returns on other trading days (Ariel ,1990; Vergin and McGinnis, 1999). These seminal papers served as a springboard for much subsequent research that confirmed the ability of variables, other than beta, to explain cross sectional differences in returns.

These regularities in stock returns, otherwise known as calendar anomalies (effects), have occupied empirical research on asset pricing models for nearly half a century, and present a paradox in empirical finance: their existence cast doubt on the validity of asset pricing models and hence challenge the belief in stock market efficiency. For 
instance, investors could buy stocks on days (months) with abnormally low returns and sell on days (months) with abnormally high returns. Further, if the pre-holiday effect holds, it is possible to devise strategies that would yield returns over and above buy and hold. These would be inconsistent with the efficient markets hypothesis $(\mathrm{EMH})$. However, since their discovery, seasonal patterns in stock returns have failed to yield consistent returns over and above buy and hold strategies. As French (1980), Board and Sutcliffe (1988), Draper and Pauydyal (1997), Brooks and Persand (2001), Mills and Coutts (1995) argue, any 'trading rules' derived from the expectations of anomalies, will be more than offset by the 'round trip' transaction costs and illiquidity. Thus small calendar specific anomalies need not violate no-arbitrage conditions. Further, it has been argued that even if there are no calendar specific effects, an extensive search (mining) over a large number of possible seasonalities is likely to yield something that appears to be an 'anomaly' by pure chance (see Lo and MacKinlay, 1990, Sullivan et al, 1999 and Burton, 2003).

For nearly half a century of their discovery in markets world wide, there has been little evidence regarding African markets ${ }^{1}$. This paper contributes to the literature on African markets. The novelty of the paper rests on the following: (a) we test for the existence of two calendar anomalies in African indices- month-of-the-year and preholiday effects (for day-of the-week effect see Alagidede, 2008). African markets have a variety of institutional features that differentiate them from one another and from the markets in industrial and other emerging economies. The search for seasonality or other anomalies in the returns of African markets can provide important information on the role of institutional features on return behaviour. This information may help stock exchange and regulatory authorities when they make policy decisions; (b) the paper explicitly accounts conditional heteroscedasticity in the month-of-the-year effects. (c) the question of whether trading rules can yield profits over buy and hold by exploiting seasonal patterns is explored.

\footnotetext{
1 The only available published research to the best of our knowledge includes Coutts and Sheikh (2002) who investigate the All Gold Index of South Africa and found no evidence of seasonality. Classens et al (1995) who find significant returns in March and June for Nigeria but no seasonality in Zimbabwe, while Alagidede (2008) investigates the day-of the week effects in 6 African stock markets.
} 
Our results indicate that the month of the year effect is more pronounced in mean than in conditional variance for Nigeria and Zimbabwe. In Egypt, only January returns are significant. With the exception of South Africa where pre-holiday effects are estimated to be $0.3 \%$, there are no pre-holiday effects in the other markets.

The rest of the paper is organised as follows: section 2 briefly outlines the literature on anomalies. We specify the general OLS approach of investigating anomalies and adjust for conditional heteroscedasticity in section 3. Evidence of month-of-the-year and preholiday effects are presented in section 4. We conclude and offer promising ideas for future research in section 5 .

\section{Calendar Effects: World Wide Evidence}

Much of the research on cross sectional predictability has focused on the relationship between returns and the market value of common equity, commonly referred to as the size effect. Banz (1981) published one of the earliest articles on the 'small-firm effect'. Banz (1981) estimated a model of the form $R_{i}=a_{0}+a_{1} b_{i}+a_{2} S_{i}+e_{i}$, where $S_{i}$ is a measure of the relative market capitalisation (size) for firm $i$ for New York Stock Exchange between 1926 and 1975. Banz documents that excess returns would have been earned over the period 1936-1975 by holding stocks of low capitalisation companies. The striking aspect of Banz's analysis is that the size effect appeared to be important in terms of both statistical significance and empirical relevancy. For instance, the return from buying very small firms versus very large firms was $19.8 \%$ per year. Further, the real pay-off from holding small stocks came from holding the smallest $20 \%$ of the firms in Banz's sample of New York Stock Exchange firms. However, while on average the return from holding the smallest firms was large and statistically significant, there were periods where large firms outperformed small firms. In the UK, Dimson and Marsh (1984) report evidence of a size effect on the portfolios constructed from a sample of stocks taken from the London Share Price Data (LSDP). Over the period 1977 to 1983 , the portfolio of smallest stocks earned a compound annual return of $41 \%$, and the portfolio of largest stocks realised a compound annual return of $18 \%$. In a follow up article, however, Dimson and Marsh (1999) produced evidence to indicate that there has been a reversal in the size effect in the London Stock Exchange. They find that during the 1990s large firms have earned greater returns than small firms. More recently, Mills and Jordanov (2003) consider the 
predictability of the size portfolio returns, both adjusted and unadjusted for risk, to examine evidence for weak form inefficiency in small firms in relation to large stocks contained in the FTSE-Actuaries All share index between 1982-1995. They rank size portfolios as percentages on a yearly basis. A conventional autocorrelation test revealed substantial evidence of predictability, with six portfolios, including the four smallest, showing evidence of significant correlations between current and either the first or second lagged portfolio return.

The implication of these findings is that market structure may be an important influence on the measured size effect. If so, then, analysis of the international evidence, where we observe very different market organisations and structures, should reveal significant differences in the magnitude of the size premium across markets. Hawawini and Keim (1999) review of the size effect from equity markets in Australia, New Zealand, Canada, Mexico, Japan, Korea, Singapore Taiwan and eight European countries, for varying periods of time show that the size premium is positive for all the countries in their sample except Korea. In terms of monthly size premium, Mexico records $4.18 \%$ between 1982-87; Australia and Japan 1.2\% and 1.2\% between 1958-81 and 1965-87 respectively. There are however significant differences across the largest markets in the spread between the size of the largest and smallest portfolios. For instance, they show that in Spain, the largest size portfolio is 228 times larger than the smallest one, whereas in the case of Taiwan it is only 17 times. They also show that the size premium in their sample during the period was most pronounced in Australia $(5.73 \%)$ and Mexico (4.16) and least significant in Canada (0.44\%) and the UK (0.40\%).

There has been extensive research into the possible explanations of anomalous returns behaviour between small and large firms. One research avenue has been to hypothesize that the CAPM was inappropriately measured causing apparent excess return. The argument is that the betas for small firms are too low. If betas are too low, then the estimate of expected return using the CAPM would be positive even if it were zero when expected return was correctly estimated.

A substantial number of studies have found that part of the size effect occurs in the month of January. The January effect refers to the anomaly where firms experience abnormal returns in the first few days of trading in January. The persistence of these returns stands in opposition to the efficient market hypothesis and as such has been a target of investigation. Rozeff and Kinney (1976) first examined the January effect, and 
they used New York Stock Exchange stocks for the period 1904 to 1974 and find that average return for the month of January was $3.48 \%$ compared to only $0.42 \%$ for the other months. Keim (1983) employ the same data set for the period 1963-79 and find that nearly $50 \%$ of the average magnitude of risk-adjusted premium of small firms relative to large firms is due to the January abnormal returns. Further, more than $50 \%$ of the January premium is attributable to large abnormal returns during the first week of trading in the year. Fama (1991) reports the results of the S\&P 500 for the period 1941-1981. In this period, small stocks averaged a return of $8.06 \%$ in January. Large stocks managed a return of $1.342 \%$.

In other markets, Kato and Shallheim (1985) examined excess returns in January and the relationship between size and the January effect for the Tokyo Stock Exchange. They find no relationship between size and return in non-January months. However, they find excess returns in January and a strong relationship between return and size, with the smallest firms returning $8 \%$ and the largest $7 \%$. Evidence also indicates that the January effect is present in other financial variables too. Keim and Stambaugh (1984) study the January return anomaly in the bond market in the period 1926-1978. They find that, on average, only in January do low quality bonds give an extra return.

In the UK, Mills and Coutts (1995) used FTSE indices between January 1986 and October 1992 and established that calendar effects exist in the FTSE 100, Mid 250 and 350 indices, and certain of the accompanying industry baskets. Internationally, the January effect has been documented in studies such as Gultekin and Gultekin (1983). Using data from 17 countries, the authors find much higher returns in January than non-January months in all the countries they studied. Returns are bigger especially for the non-US markets. There is strong evidence of the January pattern across all markets.

There is little agreement on the causes of the monthly seasonality. Competing reasons including, but not limited to tax loss selling hypothesis, microstructure issues, spurious causes such as outliers, concentration of listings and de-listing at year-end, and insider trading have been adduced. These can broadly be classified under two headings: one that is consistent with stock market efficiency and equilibrium asset pricing models, and one that is at variance with the hypothesis, Seyhun (1993). 
The tax-loss selling hypothesis posits that investors sell their losing stocks before year end in order to obtain the tax savings from deducting those losses from capital gains realised during the year (Rozeff, 1986). The selling pressure in late December is then followed by buying pressure in January as investors return to desired portfolio compositions. Fortune (1991) finds this to be inconsistent with the efficient market hypothesis because, in efficient markets, investors with no capital gains taxes should identify any tendency towards abnormally low prices in December and should become buyers of stocks oversold in late December. In effect, the tax-loss selling should affect the ownership of shares but not their price. Chan et al (1985) posits omitted risk factors as a cause for the monthly anomaly. This explanation holds that, it is riskier to hold stocks in January than in any other month of the year because of some omitted risk factors in that month. Therefore, investors, on average, get a higher return in January to compensate for these omitted risks.

There has also been an explanation linking the January effect with the small firm effect. Keim (1989) attribute this to microstructure biases. According to this explanation, the last trade in December for most stocks is at the bid price, which causes returns to appear high in the first few days of January. Keim (1989) found that the tendency for stocks to be at the bid price for the last trade in December was much pronounced for small stocks. In addition, small stocks have higher bid-ask-spread and a lower price. Therefore, the return would be bigger for small stocks and this partly explains the differences in the January effect between large and small stocks.

\section{Calendar Effects: A methodological Note}

Previous studies of stock market anomalies may in general be divided into four groups based on the methodology employed. The first group of studies calculate returns means and variances for each day (month) of the week (year) and estimate a simple OLS regression with dummies using standard $t$ of $F$ tests or ANOVA to check the significance and equality of mean returns, without paying attention to the time series properties of the sample data (see French 1980, Gibbons and Hess 1981 etc for evidence). Whereas this may give an indication of the presence or otherwise of some specific anomalies, the data generation process and misspecification effects could cast doubt on the reliability of the results reported in such studies. The second group of studies also report mean daily (monthly) returns based on OLS regressions, however, 
hypothesis tests are carried out using $t$-statistics and $\chi^{2}$ calculated using heteroscedasticity-consistent standard errors. This group does not however, examine the distributional properties of the data used. In the third group, normality of returns is tested for by means of Kolmogorov-Smirnov D statistic. If the returns are found to be normally distributed, then $t$ and F-tests or ANOVA are employed. Otherwise nonparametric tests are used to tests the existence of anomalies. The last group of studies starts by reporting descriptive statistics of the distributional properties of the return series. If these statistics indicate that the series are highly leptokurtic relative to normal distribution, the outcome provides a justification for the use of GARCH model to investigate the presence of anomalies.

This paper extends the work of the fourth group by explicitly testing for iid in the empirical residuals. The novelty of this paper rest on the following: (a) we test for the existence of two calendar anomalies in African indices - month of the year and the pre-holiday effects. African markets have a variety of institutional features that differentiate them from one another and from the markets in industrial and other emerging economies. The search for seasonality or other anomalies in the returns of African markets can provide important information on the role of institutional features on return behaviour. This information may help stock exchange and regulatory authorities when they make policy decisions; (b) the paper explicitly accounts for risk and conditional heteroscedasticity in the month of the year effects (c) the question of whether trading rules can yield profit over buy and hold by exploiting seasonal patterns; (d) we consider the reasons for the occurrence of seasonalities in African indices, if indeed they exist.

\subsection{January and Month of the Year Effect}

Monthly continuously compounded log returns is calculated as

$$
\mathrm{R}_{\mathrm{t}}=\log \left(\frac{\mathrm{P}_{\mathrm{t}}}{\mathrm{P}_{\mathrm{t}-1}}\right) * 100
$$

The standard methodology employed in investigating seasonality in monthly returns entails estimating an OLS regression with dummies to capture month of the year effects as 
$R_{t}=\alpha_{1} M_{1 t}+\alpha_{2} M_{2 t}, \ldots, \alpha_{12} M_{12 t}+\varepsilon_{t}$

$R_{t}$ is the continuously compounded index return on month $t$ as shown in (1). The $M_{i t}$ are dummy variables such that $M_{1 t}=1$ if month $t$ is January and zero otherwise; $M_{2 t}$ $=1$ if month $\mathrm{t}$ is February and zero otherwise and so forth. The OLS coefficients $\alpha_{1}$ to $\alpha_{12}$ are the mean returns for January through December respectively and $\varepsilon_{t}$ is the stochastic term. The presence of monthly seasonality implies

$\mathrm{H}_{0}: \alpha_{1}=\alpha_{2}, \ldots, \alpha_{12}=0$ against $\mathrm{H}_{1}: \alpha_{1} \neq \alpha_{2}, \ldots, \alpha_{12} \neq 0$

If the null hypothesis is rejected then stock returns must exhibit some form of monthly seasonality.

Previous evidence examined the month of the year effect in various markets in the context of equation (2) using standard $\mathrm{t}$ and F-test without paying attention to the time series properties of the data. For instance the error in the model may be autocorrelated resulting in misleading inferences. Also the error variances may not be constant over time, resulting in inefficient estimates if there is time varying variance. The first drawback is resolved by including autoregressive terms in (2). However since we are dealing with monthly data, the issue of non-synchronous trading is not so prominent in our data. The second drawback, which is of interest to us is resolved by making the variance time varying.

$\mathrm{h}_{\mathrm{t}}=\omega+\alpha \varepsilon_{\mathrm{t}-1}^{2}+\beta \mathrm{h}_{\mathrm{t}-1}+\sum_{\mathrm{i}=2}^{12} \phi_{\mathrm{i}} \mathrm{M}_{\mathrm{it}}$

where $\mathbf{M}_{\mathrm{it}}$ represents monthly dummies.

\subsection{Pre-Holiday effect}

The pre-holiday effect postulates that returns observed on days preceding a public holiday day are on average many times greater than return on other trading days (see Ariel, 1990). The Pre-holiday effect is tested via the following regression 
$R_{t}=\xi_{1} H_{1 t}+\xi_{2} H_{2 t}+\varepsilon_{t}$

where $\xi_{1}$ and $\xi_{2}$ are the mean returns for days prior to holidays and all other days respectively. $H_{1 t}$ is a dummy that takes the value of unity at all times other than days immediately preceding a public holiday where it takes a value of zero. $H_{2 t}$ on the other hand takes the value of one before a public holiday and zero at all other times. The null hypothesis that mean pre-holiday returns are equal to the mean for other days is

$H_{0}: \xi_{1}=\xi_{2}$ against $H_{1}: \xi_{1} \neq \xi_{2}$

\section{Evidence of Month of the Year and January Seasonality}

\subsection{Data employed}

The data consists of monthly stock prices for the following countries: NSE All Share Index for Nigeria, NSE20 index for Kenya, Tunnindex for Tunisia, MASI index for Morocco and FTSE/JSE All Share index, CASE30 Share Index and ZSE Industrial index for South Africa, Egypt and Zimbabwe respectively. These are the biggest markets in Africa and together they account for over $90 \%$ of stock market capitalisation and domestic company listing on the continent. The data was obtained from DataStream for various sample sizes as shown in Table I. Table I indicates that, over the sample period, monthly stock returns have averaged 0.006 to 0.082 for Egypt and Zimbabwe respectively. 
Table I: Summary Statistics of Monthly Returns (Logarithmic Returns)

\begin{tabular}{|c|c|c|c|c|c|c|c|}
\hline & Egypt & Kenya & Morocco & Nigeria & S. Africa & Tunisia & Zimbabwe \\
\hline Sample & $\begin{array}{c}1997 \mathrm{Mo} 7 \\
\text { to } \\
2006 \mathrm{Mo9}\end{array}$ & $\begin{array}{c}1990 \mathrm{Mo} 1 \\
\text { to } \\
2009 \mathrm{Mo9}\end{array}$ & $\begin{array}{c}2002 \mathrm{M} 1 \\
\text { to } \\
2006 \mathrm{M} 10\end{array}$ & $\begin{array}{c}1990 \mathrm{Mo} 1 \\
\text { to } \\
2009 \mathrm{Mo9}\end{array}$ & $\begin{array}{c}1997 \mathrm{Mo} 7 \\
\text { to } \\
2006 \mathrm{M} 10\end{array}$ & $\begin{array}{c}1997 \mathrm{M} 12 \\
\text { to } \\
2006 \mathrm{Mo9}\end{array}$ & $\begin{array}{c}1995 \mathrm{Mo6} \\
\text { to } \\
2006 \mathrm{Mo9}\end{array}$ \\
\hline Obs. & 111 & 201 & 58 & 201 & 112 & 106 & 136 \\
\hline Mean & 0.006 & 0.0086 & 0.014 & 0.024 & 0.008 & 0.007 & 0.082 \\
\hline St. Dev & 0.088 & 0.091 & 0.050 & 0.055 & 0.068 & 0.037 & 0.220 \\
\hline Skewness & 1.139 & 1.923 & 0.827 & 0.492 & -1.136 & 1.728 & 1.117 \\
\hline Kurtosis & 5.546 & 22.425 & 6.172 & 7.798 & 8.807 & 9.214 & 7.093 \\
\hline Jarque-Bera & $53.5^{* * *}$ & $3267.5^{* * *}$ & $30.38^{* * *}$ & $260.9^{* * *}$ & $179.8^{* * *}$ & $221.1^{* *}$ & $122.3^{* * *}$ \\
\hline
\end{tabular}

The distributional properties of monthly stock returns are far from being normal: for instance, we observe negative skewness in South Africa while, in general, all countries show excess kurtosis. These basic features of the monthly returns provide the rationale for adjusting for conditional heteroscedasticity. Evidence of (2) are shown in Table II.

Table II: Monthly Seasonality African Stock Returns

\begin{tabular}{|c|c|c|c|c|c|c|c|}
\hline & Egypt & Kenya & Morocco & Nigeria & South Africa & $\begin{array}{l}\text { Tunisia } \\
\end{array}$ & $\overline{\text { Zimbabwe }}$ \\
\hline January & $\begin{array}{c}0.119 * * \\
(4.26)\end{array}$ & $\begin{array}{l}0.0223 \\
(1.004)\end{array}$ & $\begin{array}{l}0.018 \\
(0.75)\end{array}$ & $\begin{array}{c}0.035^{*} \\
(2.91)\end{array}$ & $\begin{array}{l}0.032 \\
(1.43)\end{array}$ & $\begin{array}{l}0.017 \\
(1.32)\end{array}$ & $\begin{array}{c}0.282^{* * *} \\
(4.411)\end{array}$ \\
\hline February & $\begin{array}{l}-0.027 \\
(-0.99)\end{array}$ & $\begin{array}{c}0.077^{* * *} \\
(3.413)\end{array}$ & $\begin{array}{c}0.073^{* *} \\
(3.001)\end{array}$ & $\begin{array}{l}0.025^{*} \\
(2.177)\end{array}$ & $\begin{array}{c}0.046 \\
(2.02)^{*}\end{array}$ & $\begin{array}{l}0.013 \\
(1.03)\end{array}$ & $\begin{array}{c}0.00628 \\
(0.09)\end{array}$ \\
\hline March & $\begin{array}{l}-0.007 \\
(-0.25)\end{array}$ & $\begin{array}{l}-0.004 \\
(-0.171)\end{array}$ & $\begin{array}{l}0.0201 \\
(0.915)\end{array}$ & $\begin{array}{c}0.013 \\
(1.025)\end{array}$ & $\begin{array}{l}0.0002 \\
(0.011)\end{array}$ & $\begin{array}{c}0.012 \\
(0.980)\end{array}$ & $\begin{array}{l}-0.016 \\
(-0.25)\end{array}$ \\
\hline April & $\begin{array}{l}0.012 \\
(0.44)\end{array}$ & $\begin{array}{c}-0.042 \\
(-1.916)\end{array}$ & $\begin{array}{c}0.005 \\
(0.247)\end{array}$ & $\begin{array}{c}0.023^{*} \\
(2.00)\end{array}$ & $\begin{array}{l}-0.007 \\
(-0.33)\end{array}$ & $\begin{array}{l}0.017 \\
(1.39)\end{array}$ & $\begin{array}{l}0.042 \\
(0.67)\end{array}$ \\
\hline May & $\begin{array}{l}-0.039 \\
(-1.41)\end{array}$ & $\begin{array}{l}0.013 \\
(0.576)\end{array}$ & $\begin{array}{l}0.031 \\
(1.39)\end{array}$ & $\begin{array}{l}0.023 \\
(1.96)\end{array}$ & $\begin{array}{c}0.024 \\
(1.029)\end{array}$ & $\begin{array}{l}0.009 \\
(0.731)\end{array}$ & $\begin{array}{l}0.077 \\
(1.21)\end{array}$ \\
\hline June & $\begin{array}{c}-0.025 \\
(-0.904)\end{array}$ & $\begin{array}{c}0.007 \\
(0.329)\end{array}$ & $\begin{array}{l}-0.014 \\
(-0.64)\end{array}$ & $\begin{array}{l}0.051 * * \\
(4.2641)\end{array}$ & $\begin{array}{l}0.0006 \\
(0.028)\end{array}$ & $\begin{array}{l}-0.014 \\
(-1.112)\end{array}$ & $\begin{array}{l}0.112 \\
(1.76)\end{array}$ \\
\hline July & $\begin{array}{c}-0.004 \\
(-0.14 \cdot 1)\end{array}$ & $\begin{array}{c}0.017 \\
(0.764)\end{array}$ & $\begin{array}{c}-0.010 \\
(-0.459)\end{array}$ & $\begin{array}{l}0.012 \\
(0.98)\end{array}$ & $\begin{array}{l}-0.004 \\
(-0.18)\end{array}$ & $\begin{array}{c}0.011 \\
(0.863)\end{array}$ & $\begin{array}{c}0.236 * * \\
(3.70)\end{array}$ \\
\hline August & $\begin{array}{l}0.009 \\
(0.31)\end{array}$ & $\begin{array}{l}-0.0001 \\
(-0.006)\end{array}$ & $\begin{array}{l}0.014 \\
(0.65)\end{array}$ & $\begin{array}{l}0.026^{*} \\
(2.262)\end{array}$ & $\begin{array}{l}-0.015 \\
(-0.65)\end{array}$ & $\begin{array}{l}0.0101 \\
(0.793)\end{array}$ & $\begin{array}{l}0.097 \\
(1.59)\end{array}$ \\
\hline September & $\begin{array}{l}0.028 \\
(1.04)\end{array}$ & $\begin{array}{c}-0.018 \\
(-0.844)\end{array}$ & $\begin{array}{l}0.046^{*} \\
(2.14)\end{array}$ & $\begin{array}{l}0.012 \\
(0.99)\end{array}$ & $\begin{array}{l}-0.005 \\
(-0.23)\end{array}$ & $\begin{array}{l}0.0094 \\
(0.742)\end{array}$ & $\begin{array}{c}0.077 \\
(1.265)\end{array}$ \\
\hline October & $\begin{array}{c}-0.003 \\
(-0.089)\end{array}$ & $\begin{array}{c}-0.0009 \\
(-0.03)\end{array}$ & $\begin{array}{l}-0.009 \\
(-0.402)\end{array}$ & $\begin{array}{l}0.029^{*} \\
(2.44)\end{array}$ & $\begin{array}{l}-0.008 \\
(-0.36)\end{array}$ & $\begin{array}{l}-0.0039 \\
(-0.293)\end{array}$ & $\begin{array}{l}0.094 \\
(1.47)\end{array}$ \\
\hline November & $\begin{array}{l}-0.016 \\
(-0.56)\end{array}$ & $\begin{array}{l}0.026 \\
(1.16)\end{array}$ & $\begin{array}{l}-0.016 \\
(-0.66)\end{array}$ & $\begin{array}{l}0.016 \\
(1.39)\end{array}$ & $\begin{array}{l}0.041 \\
(1.79)\end{array}$ & $\begin{array}{l}-0.003 \\
(-0.225)\end{array}$ & $\begin{array}{c}0.019 \\
(0.300)\end{array}$ \\
\hline December & $\begin{array}{c}0.012 \\
(0.443)\end{array}$ & $\begin{array}{l}0.013 \\
(0.58)\end{array}$ & $\begin{array}{c}0.019 \\
(0.781)\end{array}$ & $\begin{array}{l}0.012^{*} \\
(2.15)\end{array}$ & $\begin{array}{l}-0.005 \\
(-0.21)\end{array}$ & $\begin{array}{l}0.0061 \\
(0.450)\end{array}$ & $\begin{array}{l}-0.015 \\
(-0.244)\end{array}$ \\
\hline$F$-statistic & $\begin{array}{l}3.093^{* *} \\
{[0.009]}\end{array}$ & $\begin{array}{c}1.575 \\
{[0.101]}\end{array}$ & $\begin{array}{c}1.158 \\
{[0.341]}\end{array}$ & $\begin{array}{l}2.71 * * \\
{[0.002]}\end{array}$ & $\begin{array}{c}0.881 \\
{[0.561]}\end{array}$ & $\begin{array}{c}0.550 \\
{[0.863]}\end{array}$ & $\begin{array}{l}2.995^{* * *} \\
{[0.001]}\end{array}$ \\
\hline$A I C$ & -2.120 & -1.918 & -3.0189 & -2.992 & -2.435 & -3.614 & -0.257 \\
\hline $\mathrm{SBC}$ & -1.799 & -1.7029 & -2.588 & -2.814 & -2.14 .2 & -3.31 & 0.023 \\
\hline $\operatorname{ARCH}(5)$ & $\begin{array}{c}0.298 \\
{[0.912]}\end{array}$ & $\begin{array}{c}1.078 \\
{[0.373]}\end{array}$ & $\begin{array}{c}0.531 \\
{[0.752]} \\
\end{array}$ & $\begin{array}{c}1.322 \\
{[0.401]}\end{array}$ & $\begin{array}{c}0.996 \\
{[0.423]}\end{array}$ & $\begin{array}{c}0.165 \\
{[0.974]}\end{array}$ & $\begin{array}{c}0.429 \\
{[0.871]}\end{array}$ \\
\hline
\end{tabular}

The January seasonality is evident in Egypt, Nigeria and Zimbabwe. It can be seen from Table II that, apart from January, there are no significant monthly returns for Egypt. Although monthly returns in July are significant for Zimbabwe, over all, they are not greater than the January return. Thus for these two markets (Egypt and 
Zimbabwe), we can confirm the hypothesis that mean monthly returns in January exceed other months of the year. These are estimated to be 0.12 and 0.28 for Egypt and Zimbabwe respectively. Our results contrast with Claessens et al (1995), who find no evidence of a month of the year effect for Zimbabwe. Table II also indicates seasonality in other months of the year. There is a February effect for Morocco, Kenya, Nigeria and South Africa. The hypothesis that returns for all months are equal can be rejected for Egypt, Nigeria and Zimbabwe. For four markets (Morocco, Kenya, Tunisia and South Africa) there is insignificant variation between monthly returns and none exhibit any January seasonality.

Overall the estimates show that monthly seasonality is pronounced for Nigeria; seven months record statistically significant returns, with the highest falling on the month of June. Except for Nigeria and Zimbabwe, we do not find evidence of conditional heteroscedasticity in the other countries. To this end we implement a GARCH model to further investigate the month of the year effect in the two countries (Table III).

Table III: Month of the year in Mean and Volatility

\begin{tabular}{|c|c|c|}
\hline & Nigeria & Zimbabwe \\
\hline \multicolumn{3}{|c|}{ Mean equation } \\
\hline January & 0.0209**(3.623) & $0.254 * *(4.085)$ \\
\hline February & $0.0015(0.266)$ & $-0.206^{*}(-2.59)$ \\
\hline March & $0.0043(0.606)$ & $-0.224 * *(-3.142)$ \\
\hline April & $0.0043(0.59)$ & $-0.229 * *(-3.346)$ \\
\hline May & $-0.008(1.150)$ & $-0.204 *(-2.67)$ \\
\hline June & $0.017 *(2.488)$ & $-0.169 *(-2.073)$ \\
\hline July & $0.0078(1.211)$ & $-0.154(-1.471)$ \\
\hline August & $0.0119(1.622)$ & $-0.231 *(-2.751)$ \\
\hline September & $-0.003(-0.506)$ & $-0.226 *(-3.434)$ \\
\hline October & $0.009(1.163)^{\prime}$ & $-0.219^{*}(-2.28)$ \\
\hline November & $0.007(0.870)$ & $-0.265 * *(-3.595)$ \\
\hline December & $-0.001(-0.143)$ & $-0.228 *(-2.75)$ \\
\hline -statistic & $1.2220 .2]$ & $10.25 * *[0.002]$ \\
\hline \multicolumn{3}{|c|}{ Variance equation } \\
\hline January & 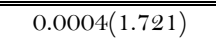 & $0.034(1.04)$ \\
\hline February & $-0.0005(-1.315)$ & $-0.053(-0.989)$ \\
\hline March & $-2.38 \mathrm{E}-05(-0.063)$ & $-0.033(-0.97)$ \\
\hline April & $-0.0006 *(-2.203)$ & $-0.0411(-1.18)$ \\
\hline May & $-0.0002(-1.132)^{\prime}$ & $-0.021(-0.610)$ \\
\hline June & $0.004(1.188)$ & $-0.030(-0.813)$ \\
\hline July & $-0.003(-1.561)$ & $0.003(0.063)$ \\
\hline August & $0.0003(0.621)$ & $-0.039(-0.87)$ \\
\hline September & $-0.0007 *(-2.54)$ & $-0.0497(-1.326)$ \\
\hline October & $0.0001(0.383)$ & $-0.009(-0.251)$ \\
\hline November & $-0.0004(-1.225)$ & $-0.046(-1.379)$ \\
\hline December & $-0.0006^{*}(-2.03)$ & $-0.029(-0.84)$ \\
\hline AIC & -3.461 & -0.433 \\
\hline SBC & -3.091 & 0.147 \\
\hline LL & 476.9 & 56.28 \\
\hline $\operatorname{ARCH}(5)$ & $1.8448[0.10469]$ & $2.223[0.1123]$ \\
\hline$F$-statistic & $0.3493[0.5550]$ & $2.0243[0.1577]$ \\
\hline
\end{tabular}

Estimates of (4) 
After accounting for conditional heteroscedasticity we find that the January seasonality is significant in both mean and variance. Throughout the sample Nigeria records 0.02 returns in January while Zimbabwe records 0.025 . We also find significant positive June returns for Nigeria while for Zimbabwe, there are more significant but negative returns in almost all months. The monthly seasonality is not very prominent in volatility. Only December, September and April have significant negative returns in Nigeria.

From these results, it appears that the turn-of-the-tax-year effects found for many industrial economies do not extend to African markets. One could attribute this to the peculiar characteristics of the trading systems and market microstructure of the countries. Equally possible, however, could be that the tax codes of these economies do not give rise to the selling of stocks at the end of the tax year to generate a loss for tax purposes, the hypothesis often cited as an explanation for the turn-of-the-tax-year effect in developed economies. In addition to tax codes that are designed differently in emerging economies (compared with industrial economies), lax legislation and poorly developed legal infrastructure, especially regarding the security markets in Africa could well explain the lack of evidence for the tax-loss-selling hypothesis.

Overall, the estimates show that monthly seasonality is pronounced for Nigeria; seven months of the year record statistically significant returns, with the highest is the month of June. This evidence confirms results by Classens et al (1995), who find June and March returns to be significant in Nigeria.

For Egypt, Nigeria and Zimbabwe, although we find significant January effects, the evidence is not convincing as to whether the tax loss selling hypothesis could be working here. For instance, we do not find evidence of any other monthly effect for Egypt, whereas for Zimbabwe and Nigeria, the January average return is not necessarily greater than other months. Further evidence is thus required to confirm these findings. The results also raise further questions which warrant further investigation. Is the January effect related to the size effect? This requires richer data 
on individual stocks than we have available here, and thus opens the door for future research. Finally, is it profitable to apply trading rules to exploit these anomalies? Here, data on transactions costs/or mutual fund spread would be required to judge the profitability of applying a trading rule on the patterns identified. Our own conclusion is that, given the current state of illiquidity in African markets, such rules may prove unprofitable.

\subsection{The Pre-Holiday Effect}

The definition of holidays varies among researchers (Brockman and Michayluk, 1998). One definition looks at days, other than Saturday or Sunday, upon which the market is closed (Lakonishok and Smidt, 1988). However, this excludes exceptional events, such as the end of apartheid in South Africa, the recent widespread political crises in Kenya that caused the market to close to traders, and natural disasters like hurricanes, etc., which can cause abrupt closure of markets. Furthermore, some holidays (e.g., Easter and most religious holidays which follow the lunar calendar) change over time. To this end, we define the holiday effect as the return from the pre-holiday close to the postholiday close. In other words, the holiday returns are the daily returns for the trading weekday that follows a non-trading weekday. We summarise these for all the countries in Table IV.

\section{Table IV: Summary of National Holidays}

\begin{tabular}{|c|c|}
\hline Egypt & $\begin{array}{l}\text { JANUARY: Coptic Christmas, Eid al Adha, El Hijra. APRIL: Prophet birthday\#, Coptic Easter, Sham el Nessim, Sinai Liberation Day. } \\
\text { MAY 1: Labour day\#. JULY 23: National Day \#. SEPTEMBER 11: Coptic New year\# .OCTOBER: Eid al Fitr } \\
\text { DECEMBER: Eid al Adha }\end{array}$ \\
\hline Kenya & $\begin{array}{l}\text { JANUARY: New Yea Day (1) \#; New Year holiday (2) \#. APRIL: Good Friday, Easter. MAY: Labour Day (1) \#. JUNE: Maraka day (1) } \\
\text { \#.OCTOBER 10: Moi Day; 20\#: Kenyatta Day; Eid al Ftr\# DECEMBER : independence day (12); Christmas day(25)\#; Boxing Day(26)\# }\end{array}$ \\
\hline Morocco & $\begin{array}{l}\text { JANUARY :New year Day }\left(1^{\text {st }}\right) \# ; \text { Eiud al Adha; Independence manifesto day }\left(11^{\text {th }}\right) \# ; \text { Islamic New year } \\
\text { APRIL: Prophets Birthday }\left(10^{\text {th }}\right) \text { \#. MAY: Labour day }(1) \# \text {. JULY: Throne day (30) \#. AUGUST: Oued Eddaha Allegiance day; } \\
\text { Revolution day }\left(20^{\text {th }}\right) \# ; \text { the Kings birthday }\left(21^{\text {st }}\right) \# . \text { OCTOBER: Eid al Ftr. NOVEMEBER: ;ndependence Day }\left(18^{\text {th }}\right) \# \\
\text { DECEMBER: Eid al Adha }\end{array}$ \\
\hline Nigeria & $\begin{array}{l}\text { JANUARY: New year }\left(1^{\text {st }}\right) \# \text {; Id el Kabir. APRIL: The Prophets birthday }\left(10^{\text {th }}\right) \text { \#; Good Friday; Easter. MAY: labour Day (1) \#; } \\
\text { Democracy Day }\left(29^{\text {th }}\right) \# \text {. OCTOBER: National Day }\left(1^{\text {st }}\right) \# \text {; National Holiday }\left(2^{\text {nd }}\right) \# ; \text { Id el ftr. DECEMBER: Christmas }\left(25^{\text {th }}\right) \# \text {; } \\
\text { Boxing day }\left(26^{\text {th }}\right) \# \text {; Id el Kabir. }\end{array}$ \\
\hline S_Africa & $\begin{array}{l}\text { JANUARY: New year }\left(1^{\text {st }}\right) ; \text { public holiday }\left(2^{\text {nd }}\right) \# \text {. MARCH: Human Rights Day. APRIL: Good Friday; Easter; Freedom day }\left(27^{\text {th }}\right) \# \\
\text { MAY: Workers day }(1) \# . \text { JUNE: Youth day. AUGUST: Women's Day. SEPTEMBER: Heritage day; Public holiday. } \\
\text { DECEMBER: World Aids Day }\left(1^{\text {st }}\right) \# ; \text { Day of Reconciliation }\left(16^{\text {th }}\right) \# ; \text { Christmas Day }\left(25^{\text {th }}\right) \# ; \text { Good will day }\left(26^{\text {th }}\right) \#\end{array}$ \\
\hline Tunisia & $\begin{array}{l}\text { JANUARY: New Year }\left(1^{\text {st }}\right) \text { \#; Islamic New Year }\left(31^{\text {st }}\right) \text { \#. MARCH: Independence Day }\left(20^{\text {th }}\right) \text {; Youth Day. APRIL: martyrs Day. } \\
\left.\text { MAY: Labour day (1) \#. JULY: Republic day }(25) \text { \#. AUGUST: Women's Day. OCTOBER: Korite. NOCVEMBER: New Era Day (7 } 7^{\text {th }}\right) \\
\text { \#.DECEMBER: Tabsaki(31)\# }\end{array}$ \\
\hline Zimbabwe & $\begin{array}{l}\text { JANUARY: New Year }\left(1^{\text {st }}\right) \# \text {; New year holiday }\left(2^{\text {nd }}\right) \# \text {. APRIL: Good Friday; Easter; Independence Day }\left(18^{\text {th }}\right) \text { \#. MAY: Labour day }(1) \# \text {; } \\
\text { Africa Day }\left(25^{\text {th }}\right) \text { \#. AUGUST: Heroes day }(14) \# \text {; Defence Forces day }\left(15^{\text {th }}\right) \text { \#. DECEMBER :Unity Day }\left(22^{\text {nd }}\right) \# ; \text { Christmas } \\
\text { Day }\left(25^{\text {th }}\right) \# ; \text { Boxing Day }\left(26^{\text {th }}\right) \#\end{array}$ \\
\hline
\end{tabular}

Notes: \# holidays that occurred throughout the sample period in each country. The day in question are given in parenthesis. 
From Table V, for the entire estimation period, the average pre-holiday return (apart from South Africa) and that for all other days are insignificant. Thus, apart from South Africa, there are no pre-holiday effects in our sample.

Table V: Pre-Holiday Effect in African Stock Returns

\begin{tabular}{|c|c|c|c|c|c|c|c|}
\hline & Egypt & Kenya & Morocco & Nigeria & South Africa & Tunisia & Zimbabwe \\
\hline Pre-Holiday & $-0.003(-0.21)$ & $-0.002(-1.21)$ & $0.0003(0.32)$ & $-0.002(-0.219)$ & $0.003 *(3.107)$ & $0.0002(0.361)$ & $-0.0017(-1.082)$ \\
\hline Other & $0.001(0.91)$ & $0.001(0.87)$ & $0.0007(0.768)$ & $-0.0012(-1.592)$ & $0.0003(0.351)$ & $-0.0007(-1.57)$ & $-0.002(-1.528)$ \\
\hline$F$-stat & $0.268[0.604]$ & $0.198[0.65]$ & $0.862[0.353]$ & $2.66[0.102]$ & $6.735 * *[0.009]$ & $1.239[0.289]$ & $4.503^{*} *[0.034]$ \\
\hline
\end{tabular}

Estimates of $(5)$

Yet again, the results reported in Table $\mathrm{V}$ represent significant departures from the empirical literature on other markets. For the six markets with no pre-holiday effect, we can surmise that negative information does not arise in the days immediately before a holiday. This, however, is an unlikely explanation since the general consensus is that information (negative or positive) arises randomly. The results could also be specific to African markets microstructure, and further evidence is required to explain this. For South Africa, the market is more developed and tends to have features similar to those of developed economies. It could be that the pre-holiday effect reported in developed economies is also present in this market. We are, however, unable to disentangle the particular type of holiday responsible for this pre-holiday effect. Again, this would require more data and further evidence.

\section{Conclusion}

Calendar effects are now accepted stylized facts in stock markets world-wide. However, the research on African stock markets regarding this issue is virtually non-existent. In this paper we investigated two popular anomalies: January and pre-holiday effects. Our key conclusions are:

a) The pre-holiday effect is only significant for South Africa. There are high and significant returns in days preceding a holiday, but this finding is not applicable to the other stock markets in our sample.

b) January returns are positive and significant for Egypt, Nigeria and Zimbabwe. February returns are higher for Kenya, Morocco and South Africa. Tunisia has no monthly seasonality.

The evidence presented in this paper represents the first attempt at modelling the two seasonalities in African markets to the best of our knowledge. This leaves important 
areas where future research is warranted. First, is the January effect manifested by the size effect? Second, do the seasonal patterns uncovered in our study yield returns over and above buy and hold? These issues demand further research.

The discovery of statistically significant anomalies could imply the ability of trading rules to yield superior outcomes if they are also economically significant. This would clearly violate the EMH. These are too small to economically justify the deployment of trading rules, and hence do not present any challenge to the no arbitrage condition. Moreover, investors must incur transactions cost to exploit them, and given the illiquidity of African markets the use of trading rules might not yield profits over and above a simple buy and hold strategy. 


\section{References}

Alagidede, P. (2008), "Day of the week seasonality in African stock markets", Applied Financial Economics Letters 4(2), 115-120.

Ariel, R. (1990), "High Stock Returns before Holidays: Existence and Evidence of Possible Causes," Journal of Finance, 45(5), pp. 1611-1626.

Banz, R. (1981), "The Relationship between Return and Market value of Common Stocks," Journal of Financial Economics, 9, pp. 3-18.

Basu, S. (1977), "Investment Performance of Common Stocks in Relation to their Price-Earning Ratios: A test of the Efficient Market Hypothesis", Journal of Finance, 32, pp. 663-682.

Brockman, P., and Michayluk, D. (1998), "The Persistent Holiday Effect: Additional Evidence”, Applied Economics Letters, 5, pp. 205-209.

Brooks, C., and Persand, G. (2001), "Seasonality in Southeast Asian Stock Markets: Some New Evidence on the day-of-the-week effects", Applied Economics Letters, 8(155), pp. 158.

Burton, M.G.(2003), “The Efficient Market Hypothesis and its Critics”, Journal of Economic Perspectives, 17(1), pp. 59-82.

Chan, K.C., Chen, N., and Hsieh, D.A (1985), "An Exploratory Investigation of the Firm Size Effect”, Journal of Financial Economics, 14, pp. 451-471.

Claessens, S., Dasgupta, S., Glen, J. (1995), "Return behaviour in emerging stock markets”, World Bank Economic Review 9(1), pp.131-151.

Coutts, J.A., and Sheikh, M.A.(2002), “The Anomalies that aren't there: the weekend, January and Pre-Holiday effects on the all Gold Index on the Johannesburg Stock Exchange 1987-1997”, Applied Financial Economics, 12, pp. 863-871.

Dimson, E., and Marsh, P. (1999), “Murphy's Law and Market Anomalies”, Journal of Portfolio Management, 19(1), pp. 41-51.

Dimson, E., and Marsh, P. (1984), "The Impact of Small Firm Effect on Event Studies and the Performance of Published UK Stock Recommendation", Journal of Financial Economics, 17, pp. 113-142.

Draper, P., and Paudyal, K. (1997), "Microstructure and Seasonality in the UK Equity Market," Journal of Business Finance and Accounting, 24, pp. 1177-11204.

Fama, E.F. (1991), “Efficient Capital Markets: II,” Journal of Finance, XLVI (5), pp. $1575-1617$.

French, K.R. (1980), "Stock Returns and the Weekend Effect", Journal of Financial Economics, 8, pp. 55-69. 
Fortune, P. (1991), “Stock Market Efficiency: An Autopsy”, New England Economic Review, pp. 17-40.

Gibbons, M.R., and Hess, P.J. (1981), "Day of the Week Effect and Asset Returns", Journal of Business, 54, pp. 579-596.

Gultekin, M.N., Gultekin, N.B. (1983), "Stock Market Seasonality: International Evidence”, Journal of Financial Economics, 12, pp. 469-48 1.

Hawawini, G., and Keim, D.B. (1999), "The Cross Section of Common Stock Returns: A Review of the Evidence and Some New Findings", in Keim D.B and Ziemba, W.T (2000), Security Markets Imperfections in Worldwide Equity Markets, Cambridge University.

Kato, K., and Shallheim, J. (1985), "Seasonal and Size Anomalies in the Japanese Stock Market," Journal of Financial and Quantitative Analysis, 20(2), pp. 243-260.

Keim, D.B. (1983), "Size Related Anomalies and Stock Return Seasonality: Further Empirical Evidence”, Journal of Financial Economics, 12, pp. 13-32.

Keim, D.B., and Stambaugh, R.F. (1984), “A Further Investigation of the Weekend Effect in Stock Returns”, Journal of Finance, 39(3), pp. 819-840

Keim, D.B. (1989), "Trading Patterns, Bid-Ask-Spreads, and Estimated Security Returns: The Case of Common Stocks at Calendar Turning Points", Journal of Financial Economics, 25, pp. 75-97.

Lakonishok, J., and Smidt, S.(1988), "Are Seasonal Anomalies Real? A Ninety-Year Perspective", Review of Financial Studies, 1(4), pp. 403-425.

Lo, A.W., and MacKinlay, A.C. (1990), "Data-Snooping Biases in Tests of Financial Asset Pricing Models", Review of Financial Studies, 3(3), pp. 431-461.

Mills, T.C., and Coutts, J.A. (1995), "Calendar Effects in the London Stock Exchange FTSE Indices”, European Journal of Finance, 1, pp. 79-93.

Mills, T.C., and Jordanov, J.V. (2003), "The Size Effect and the Random Walk Hypothesis: Evidence from the London Stock Exchange Using Markov Chains", Applied Financial Economics, 13, pp. 807-815.

Rozeff, M.S., and. Kinney, W.R.(1976), "Capital Market Seasonality: The Case of Stock Returns”, Journal of Financial Economics, 3, pp. 379-402.

Rozeff, M.S. (1986), “Tax loss selling: evidence from December stock returns and share shifts," Proceedings of the Seminar on the Analysis of Security Prices. Center for Research in Security Prices, pp. 9-45.

Seyhun N. (1993), "Can Omitted Risk Factors explain the January Effect? A stochastic Dominance Approach”, Journal of Financial and Quantitative Analysis, 28, pp. 195212. 
Sullivan, R., Timmerman, A., and White, H. (2001), "Dangers of Data Mining: The Case of Calendar Effects in Stock Returns," Journal of Econometrics, 105(1), pp. 249-286.

Vergin, R.C., and McGinnis, J. (1999), "Revisiting the Holiday Effect: Is it on Holiday?”, Applied Financial Economics, 9(5), pp. 477-482. 